\title{
A Diagnostic Study of Constraints to Achieving Yield Potentials of Cocoa (Theobroma cacao L.) Varieties and Farm Productivity in Nigeria
}

\author{
Peter Osobase Aikpokpodion (Corresponding author) \\ Department of Genetics \& Biotechnology \\ University of Calabar, PMB 1115 Calabar, Nigeria \\ E-mail: paikpokpodion@yahoo.com \\ Stephen Oluwaseun Adeogun \\ Department of Agricultural Administration, \\ University of Agriculture, Abeokuta, Nigeria
}

Received: January 17, 2011

Accepted: February 17, 2011 Published: December 1, 2011

doi:10.5539/jas.v3n4p68

URL: http://dx.doi.org/10.5539/jas.v3n4p68

\begin{abstract}
Increasing farm productivity is a major breeding objective in crop improvement of any crop species. However, there is usually a gap between yields reported in experimental station and that obtained by farmers. In this study, diagnostic tools of Metaplan, Pair wise ranking, Stakeholders' analysis and Venn diagram were used within a participatory Focus Group Discussion (FGD) with farmers in the three major cocoa growing States of Nigeria, namely, Ondo, Osun and Cross River States to identify causes of low farm productivity and constraints to cocoa cultivation in Nigeria. Results showed the black pod disease (Phytophthora pod rot), old age of cocoa trees, poor access to improved planting materials, termite infestation and insufficient chemicals as the most important factors responsible for low cocoa yields obtained by farmers. We also found that local buying agents, extension outfits of national agricultural development projects (ADPs) and farmer field schools (FFS) and farmers' organizations (FOs) were the closest stakeholders to cocoa farmers in the States investigated. This study revealed the need for development of improved cocoa varieties that are resistant to the black pod disease and a functional system of seed distribution to facilitate greater access to improved varieties. We therefore suggest that programmes should be designed to increase farmers' access to improved planting materials, inputs, finance and involvement in participatory problem-identification and solution strategies development process.
\end{abstract}

Keywords: Cocoa, Farmer-participation, Improvedvariety, Yield

\section{Introduction}

Cocoa cultivation has taken place in Nigeria for more than a century since introduction in the late $19^{\text {th }}$ century. The export of cocoa beans accounts for the largest single non-oil foreign earning commodity and contributes significantly to Nigeria's Gross Domestic Product (GDP). Cocoa cultivation is made largely by smallholder farmers over an area of one to five hectares per farming household. In spite of research efforts aimed at developing improved planting materials and technological packages for improved cocoa cultivation, farmers have largely continued to adhere to their old practices and used unselected planting materials (Aikpokpodion et al., 2005). Consequently, smallholder farmers obtain yields which are much lower than potential yields obtainable in West Africa. In Africa region, the average yields obtained by farmers ranges between 100 to $500 \mathrm{~kg} / \mathrm{ha}$ (Gockowski, 2004). Nigeria is currently the $4^{\text {th }}$ cocoa producer with some 500,000 metric tonnes in 2007/2008 (FAOSTAT, 2007). These low yields have been attributed to non-use of improved planting materials, numerous pests and diseases of cocoa, old age of cocoa farms due to non-adoption of research recommendations and old age of cocoa farmers. One major question, therefore, was, in spite of several recommended technologies, including improved planting materials with high yield and disease resistance potentials developed and available at the research station, why has these not translated to increased yield and farm productivity on farmers' fields? 
Uptake of innovations by farmers is encouraged when farmers are involved in all aspect of research from problems identification stage to point of implementation and analysis of research results (Chamber, 1989; Asiabaka, 2002). A very important purpose of participatory approaches is the empowerment of the farmers and other resource-poor. Participatory research approach helps to increase farmers' capacity for research, innovation and informed decision-making and stimulate farmers to become facilitators of their own research and learning process (Asiabaka, 2002).

A large number of participatory tools are available for assisting in collecting and analyzing local information and situation (Jones et al., 2005). These tools include Livelihood analysis, Resource (or wealth) ranking, Institutional analysis, Seasonal calendar, Gender analysis, Flow diagram, Ranking techniques (which include Preference ranking, Pairwise ranking, and Matrix ranking), Causal diagram, Mapping and Participatory budgeting. Jones et al. (2005) also identified four stages of participatory research and extension approach including situation analysis and social mobilization, action planning, farmer experimentation and experience sharing stages.

Using participatory approaches in selected cocoa producing states of Nigeria, this study was conducted to identify the factors limiting attainment of optimum yields of cocoa within the context of their production milieu, determine various stakeholders working with cocoa farmers and ascertain the expected roles of all identified stakeholders in solving identified problems.

\section{Methodology}

\subsection{Study area}

Three cocoa growing States (Ondo, Osun and Cross River) in Nigeria were selected for this study based on their agro-ecological locations and contribution to the national cocoa bean output due to intensive cocoa cultivation in these areas. The participatory diagnosis for the project was carried out in three locations namely;

Wasimi Village in Ondo State (the largest cocoa producing State in Nigeria located in the south western Nigeria).

Etomi Village in Cross Rivers State (the second largest producing State located in the southeast agro ecological zone of Nigeria).

Ikoromaja Vilage in Osun State (the third largest cocoa producing State in south western Nigeria).

\subsection{Diagnostic tools}

Four tools, namely, metaplan, pairwise ranking, venn diagram and stakeholder analysis were used with the participation of farmers in this study to identify major constraints to cocoa improvement in Nigeria.

Metaplan: This tool was used with cocoa farmers to identify the various constraints militating against cocoa improvement in Nigeria. Farmers were asked to make a list of constraints facing cocoa improvement and write each one on a card. The farmers were asked to hand in one card (with the most important problem to that farmer) per round. The farmers were then led to classify the listed constraints into clusters to obtain a consensus list of constraints identified by all participants.

Pair wise ranking: This tool was used with cocoa farmers to determine the order of importance of each constraint identified by the farmers as affecting cocoa improvement in Nigeria. This was done after cocoa farmers had ranked constraints identified using metaplan. A group discussion was held among the farmers to rank each constraint already identified and compare them in a participatory manner with one another to allow decision making on the most significant constraints. The scores and rank were determined with the farmers after the comparison had been made. From the ranking, the most and the least important constraints were determined depending on the score of each of the constraints. The farmers also discussed the ranking of the constraints to identify the most important constraints affecting cocoa improvement in their locality.

Stakeholders' analysis: This tool was used with the farmers to identify the types of interaction between cocoa farmers' communities and various stakeholders involved in cocoa production in Nigeria.

Venn diagram: This was used with the farmers to determine the closeness of various institutions/organizations to cocoa farm communities.

\section{Results and discussion}

\subsection{Problem identification}

In all the States studied, the metaplan technique revealed that black pod disease, old age of cocoa trees, mirid attack, bryophytes infestation of tree trunk, insufficient chemicals, termite infestation and accessibility to planting materials were the common constraints to cocoa improvement (Table 1). Most of these constraints were 
identified in at least two of the three states. This showed that these constraints were common to all these states and therefore can be seen as a serious problems affecting cocoa improvement in Nigeria. The black pod disease is a fungal disease that thrives in wet and cold conditions and has the potential to destroy around $40 \%$ of Nigeria's annual cocoa output if farms were not sprayed with fungicides (Dowjones, 2007).

\subsection{Ranking of constraints}

Using the pairwise ranking method (Tables $2-4$ ), the old age of cocoa trees ranked first among all the constraints listed by cocoa farmers in Ondo and Cross River States. However, the black pod disease came second and third in Cross River in Ondo States, respectively. This show that old age of cocoa trees in conjunction with non-availability of planting material and poor access of cocoa farmers to planting materials as identified by cocoa farmers and the black pod disease are the most serious problems affecting cocoa improvement in Nigeria. The loss in yield attributable to pest and diseases has been estimated at $30 \%$ to $40 \%$ of global production (ICCO, 2007) and in economic terms, the black pod disease has been shown as the most serious disease of cocoa in Nigeria (Tijani, 2005).

\subsection{Stakeholders' analysis}

Various stakeholders providing some kind of support to cocoa production were identified in study communities (Figure 1 -3). These include farmers' organizations, licensed buying agents, Cocoa Research Institute of Nigeria (CRIN), Agricultural Development Projects (ADPs)/Ministry of Agriculture and Natural Resources (MANR), Cocoa Association of Nigeria (CAN), Agricultural Banks, National Cocoa Development Committee (NCDC), Cocoa Farmers Association of Nigeria (CFAN), Agrochemical Industries, Processors, Produce Inspectors, Sustainable Tree Crop Programme (STCP). Analysis showed that farmers received some kind of support from these stakeholders including finance, input supply, information and technical advice while farmers provided feedback to the stakeholders in respect of support received from the stakeholders.

The analysis across the states showed that farmers always provided feedback to all the stakeholders identified at varying degree. In Ondo State, the strongest feedback from farmers went to the STCP, followed by ADP, cocoa buyers, CRIN, processors, produce inspectors and chemical companies, in that order. The strong feedback from farmers to the STCP could be attributed to the implementation of the Farmers Field Schools in Ondo State. The weak and irregular feedback to agrochemical industries could be attributed to their low interaction with the cocoa farmers due to farmers' inability to purchase some of the chemicals as a result of their high prices. In Osun and Cross River States, the farmers' evaluation revealed that there was no significant difference in the feedback to the various organizations in these States. In respect of information flow, the study showed that there was information flow between farmers and other stakeholders except the NCDC. This could be attributed to the arrangement of the NCDC input distribution, where input from NCDC is usually distributed to farmers through commodity association and the ADPs.

Farmers from Osun State in their evaluation revealed that the support from the Agricultural Bank is weak and very irregular. Farmers during the evaluation claimed that most agricultural banks give loan to rich or political farmers with little or no consideration for the practicing cocoa farmers. However, the study showed that farmers obtained soft loan from licensed buying agents, but repaid the loan with their cocoa beans after harvest. The farmers during the study complained that the licensed buying agents collect almost twice the amount given to them in form of cocoa bean. According to the farmers, the conditions attached to such loans are not usually favorable to cocoa farmers, but they usually opted for the option due to poverty and inability to take care of their farms and in some cases, use these loans for other things such as payment of children school fees.

\subsection{Stakeholder linkage analysis}

The Venn diagrams in Figures 4-6 show the closeness of all the stakeholders identified by the cocoa farmers in all the states to the farmers' communities. The Venn diagram revealed that stakeholders like CFAN, LBAs, STCP, and ADPs are very close to the farmers' communities. In Ondo State for example, the Tonikoko Farmers Union and the STCP are very close to the farmers' community. The closeness of the STCP could be attributed to the impact of Farmer Field School on cocoa farmers' activities in the State, being the first State where the Farmer Field School (FFS) approach was introduced in Nigeria. The closeness of TFU could be attributed to the help being rendered to cocoa farmers in Ondo State in respect of cocoa marketing. The organization has been able to provide a good platform for cocoa farmers to sell their cocoa at a very good price. In Cross River State, cocoa farmers did not consider any of the stakeholders to be the closest to their communities. There was no significant difference in the closeness of most of the stakeholders to farmers' community (Fig. 5). However, CFAN, STCP and LBAs appeared to be closer to cocoa farmers' communities than other stakeholders. This 
implies that intervention to promote cocoa improvement should place emphasis on the input from these stakeholders in the State.

\section{Conclusions and Recommendations}

In this study, we found that the black pod disease caused by Phytophthora megakarya, old age of cocoa trees, poor access to improved planting materials for new planting were among the most prominent causes of low yield and crop productivity in farmers' fields in Nigeria. Other factors include termite attack, mirid (Sahlbergella singularis) infestation and inadequate chemicals for pest control. This suggests that attention should be given to these constraints to enhance cocoa improvement in Nigeria. The study also revealed that stakeholders such as ADPs, STCP, LBAs and farmers' organizations were the closest to the farmers' community. These stakeholders provide finance, technical and market information and inputs supports to cocoa farmers at varying degrees.

In view of the recent call to ensure that cocoa farmers comply with European Union regulations Maximum Residual Limits (MRLs), there is therefore, the need to encourage farmers to adopt the use of management practices that will minimize the use of chemicals on cocoa farms. Farmers should be enlightened on the use of other management practices rather than concentrating on chemicals to manage black pod diseases. It will therefore be imperative to get improved planting materials with high levels of resistance to the farmers for planting. The old age of cocoa trees was identified as a serious constraint by cocoa farmers during the focus group discussion. It is therefore recommended that input centres should be made available in all cocoa producing states in Nigeria. This can be achieved by establishing cocoa seed gardens in the various agro ecological zones in close proximity to the farmers so they can access improved planting materials for rehabilitation and replanting of their old stocks.

The stakeholders working closely to cocoa farmers should be encouraged to be involved in development of research agenda for cocoa improvement in Nigeria. To bridge the wide gap with farmers, Agricultural Banks should be encouraged to make credit facilities available to practicing cocoa farmers and not political farmers as claimed by farmers. This will ensure realization of the objectives why those banks were established in the first place and this will in turn spin off active economic activities and gainful employment of adults that can be involved in the agricultural sector of the economy

\section{References}

Adejumo, T.O. (2005). Crop Protection Strategies for major Diseases of Cocoa, Coffee and Cashew in Nigeria. Afr. J. Biotech., 4(2): 143-150.

Aikpokpodion, P.O., Badaru, K., Kolesnikova-Allen, M., Ingelbrecht, I., Adetimirin, V.O. \& Eskes, A. (2005). Farmer-researcher participatory on-farm selection of improved cocoa varieties: the Nigerian experience. In: Bekele Frances L. (ed.), End Michelle (ed.) \& Eskes Albertus (ed.). Proceedings of the International workshop on cocoa breeding for improved production systems: 19th-21th October 2003, Accra, Ghana. Reading: INGENIC, p. 183-188. International Workshop on Cocoa Breeding for Improved Production Systems. 4, 2003-10-19/2003-10-21, Accra, Ghana.

Asiabaka, C. (2002). Promotion Sustainable Extension Approaches: Farmers Field School (FFS) and its role in Sustainable Agricultural Development in Africa. [Online] Available: www.infoteca.cnptia.embrapa.br/...PROCI(OP2009.00064).pdf

Amusan, O.A., Amusan, F.O., Ademola, B. \& Oguntade, P. (2005). Quality Management Practices. In Cocoa Production in South-Western Nigeria. [Online] Available: http://www.tropentag.de/2005/abstracts/full/29.pdf

Chamber, R. (1989). Rural Development: Putting the Last First London, Longman.

Downjones. (2007). SW Nigeria Cocoa Merchants, Exporters Face Supply Problem. In Down Jones Newswire. [Online] Available: http://www.flex-news-food.com/pages/12217/Africa/Cocoa/sw_nigeria_cocoa_merchants exporters_face_supply_problem_dj.html

FAOSTAT. (2007). Food and Agriculture Organisation Statistics. [Online] Available: http://faostat.fao.org/site/291/default.aspx. Verified 11 December 2009. FAO, Rome.

Gockowski, J.J. (2004). Labour and land issues in West Africa. In: Cocoa Futures. Flood J. and Murphy R. (eds). Feriva S.A. Cali Columbia CABI commodities. CABI Bioscience. The Commodities Press. pp $114-127$.

ICCO. International Cocoa Organization. (2008). Pest and Diseases. ICCO Publication February 15, 2008. [Online] Available: http://www.icco.org/default.aspx 
Jones, J., Ellis, S., Schulz, D., Chikoye, N., de Haan, Kormawa, P. \& Adedzwa, D. (2005). Participatory Research and Extension Approaches. Research Guide, 71. International Institute of Tropical Agriculture. IITA.

STCP: Sustainable Tree Crop Program. (2005). External Review Endorses STCP. STCP Newsletter Issue No. 10 March - April 2005 Published by the IITA.

Tijani, A.A. (2005). Profitability of fungicide use decision among cocoa farmers in South-western Nigeria. $J$. of Social Sc., 11(2):165-171.

Table 1. Metaplan showing constraints to cocoa production identified by farmers in Cross River, Ondo and Osun States of Nigeria

\begin{tabular}{|l|l|l|}
\hline Ikoromaja, Osun & Wasimi, Ondo & Etomi, Cross River \\
\hline Black Pod & Black Pod & Capsid \\
Mirid & Mirid & Insufficient Chemicals \\
Termite & Termite & Poor Pricing \\
Bryophyte & Bryophyte & Black Pod \\
Sudden death & Sudden death & Stem Borer \\
Steam girdler & Stem girdler & Ripening of small pods \\
Poor Pricing & Poor Pricing & Old age of cocoa \\
Low Production & Low Production & Poor Road Network \\
Adulterated Chemicals & Adulterated Chemicals & High cost of labour. \\
Accessibility to planting materials. & Accessibility to planting materials. & \\
Poor soils & Poor soils & \\
\hline
\end{tabular}

Table 2. Pairwise ranking showing the position of constraints identified by cocoa farmers in Cross River State

\begin{tabular}{|l|l|c|c|c|c|c|c|c|c|c|c|c|}
\hline & $\mathrm{M}$ & $\mathrm{AC}$ & $\mathrm{PP}$ & $\mathrm{BP}$ & $\mathrm{SB}$ & $\mathrm{CW}$ & $\mathrm{OA}$ & $\mathrm{PR}$ & HCL & Score & Position \\
\hline 1 & Mirid (M) & $\mathrm{X}$ & 2 & 1 & 4 & 5 & 6 & 7 & 1 & 9 & 2 & $7^{\text {th }}$ \\
\hline 2 & $\begin{array}{l}\text { Insufficient \& adulterated } \\
\text { chemicals (AC) }\end{array}$ & & $\mathrm{X}$ & 3 & 2 & 2 & 2 & 7 & 2 & 2 & 6 & $2^{\text {nd }}$ \\
\hline 3 & Poor price of cocoa beans (PP) & & & $\mathrm{X}$ & 4 & 5 & 6 & 7 & 3 & 3 & 3 & $5^{\text {th }}$ \\
\hline 4 & Black pod (BP) & & & & $\mathrm{X}$ & 4 & 4 & 7 & 4 & 4 & 6 & $2^{\text {nd }}$ \\
\hline 5 & Stem borer (SB) & & & & & & $\mathrm{X}$ & 6 & 6 & 6 & 5 & $4^{\text {th }}$ \\
\hline 6 & Cherelle wilt (CW) & & & & & & & $\mathrm{X}$ & 7 & 7 & 7 & $1^{\text {st }}$ \\
\hline 7 & Old age of trees (OA) & & & & & & & & $\mathrm{X}$ & 8 & 1 & $9^{\text {th }}$ \\
\hline 8 & Poor road (PR) & & & & & & & & & $\mathrm{X}$ & 2 & 7 th \\
\hline 9 & High cost of labour HCL) & & & & & & & & \\
\hline
\end{tabular}

Table 3. Pair wise ranking showing the positioning of problems identified by cocoa farmers in Ondo State

\begin{tabular}{|l|l|l|l|l|l|l|l|l|l|l|l|}
\hline & & PP & HPC & AC & OA & IL & BP & IRR & T & Score & Position \\
\hline 1 & Poor price of cocoa (PP) & $\mathrm{X}$ & 1 & 3 & 4 & 1 & 6 & 1 & 8 & 3 & $5 t h$ \\
\hline 2 & $\begin{array}{l}\text { High price of chemicals and inputs } \\
\text { (HPC) }\end{array}$ & & $\mathrm{X}$ & 3 & 4 & 2 & 6 & 2 & 8 & 2 & $6 t h$ \\
\hline 3 & Adulterated chemical AC) & & & $\mathrm{X}$ & 4 & 4 & 3 & 3 & 8 & 4 & $4 t h$ \\
\hline 4 & Old age (OA) & & & & $\mathrm{X}$ & 4 & 6 & 4 & 8 & 6 & $1 s t$ \\
\hline 5 & Inadequate loan (IL) & & & & & $\mathrm{X}$ & 6 & 5 & 8 & 1 & $7 t h$ \\
\hline 6 & Black pod (BP) & & & & & & & $\mathrm{X}$ & 7 & 1 & $7 t h$ \\
\hline 7 & Irrigation (IRR) & & & & & & & & $\mathrm{X}$ & 6 & $1 s t$ \\
\hline 8 & Termite (T) & & & & & \\
\hline
\end{tabular}


Table 4. Pair- wise ranking showing the positioning of the problems in Osun State

\begin{tabular}{|c|c|c|c|c|c|c|c|c|c|c|c|c|c|c|}
\hline & & $\mathrm{BP}$ & $\mathrm{M}$ & $\mathrm{T}$ & $\mathrm{B}$ & SD & SG & PP & $\mathrm{AC}$ & $\mathrm{PV}$ & APM & PS & Score & Position \\
\hline 1 & Black Pod (BP) & $\mathrm{X}$ & 1 & 1 & 1 & 1 & 1 & 1 & 1 & 1 & 1 & 1 & 10 & $1 s t$ \\
\hline 2 & Mirid (M) & & $\mathrm{X}$ & 2 & 2 & 2 & 2 & 2 & 8 & 2 & 10 & 2 & 7 & $3 r d$ \\
\hline 3 & Termite $(\mathrm{T})$ & & & $\mathrm{X}$ & 3 & 3 & 3 & 3 & 8 & 3 & 10 & 11 & 5 & 5 th \\
\hline 4 & Bryophyte (B) & & & & $\mathrm{X}$ & 4 & 4 & 4 & 8 & 4 & 10 & 11 & 4 & $7 t h$ \\
\hline 5 & Sudden Death (SD) & & & & & $X$ & 5 & 7 & 8 & 5 & 10 & 11 & 2 & 9th \\
\hline 6 & Stem Girdler (SG) & & & & & & $\mathrm{X}$ & 7 & 8 & 6 & 10 & 11 & 1 & 10th \\
\hline 7 & Poor Pricing (PP) & & & & & & & $\mathrm{X}$ & 7 & 7 & 10 & 7 & 5 & 5 th \\
\hline 8 & $\begin{array}{l}\text { Adulterated Chemicals } \\
\text { (AC) }\end{array}$ & & & & & & & & $\mathrm{X}$ & 8 & 10 & 8 & 7 & $3 r d$ \\
\hline 9 & Poor Variety (PV) & & & & & & & & & $\mathrm{X}$ & 10 & 9 & 9 & 10th \\
\hline 10 & $\begin{array}{l}\text { Access to planting } \\
\text { materials (APM) }\end{array}$ & & & & & & & & & & $\mathrm{X}$ & 10 & 9 & $2 n d$ \\
\hline 11 & Poor Soil (PS) & & & & & & & & & & & $\mathrm{X}$ & 4 & 7 th \\
\hline
\end{tabular}

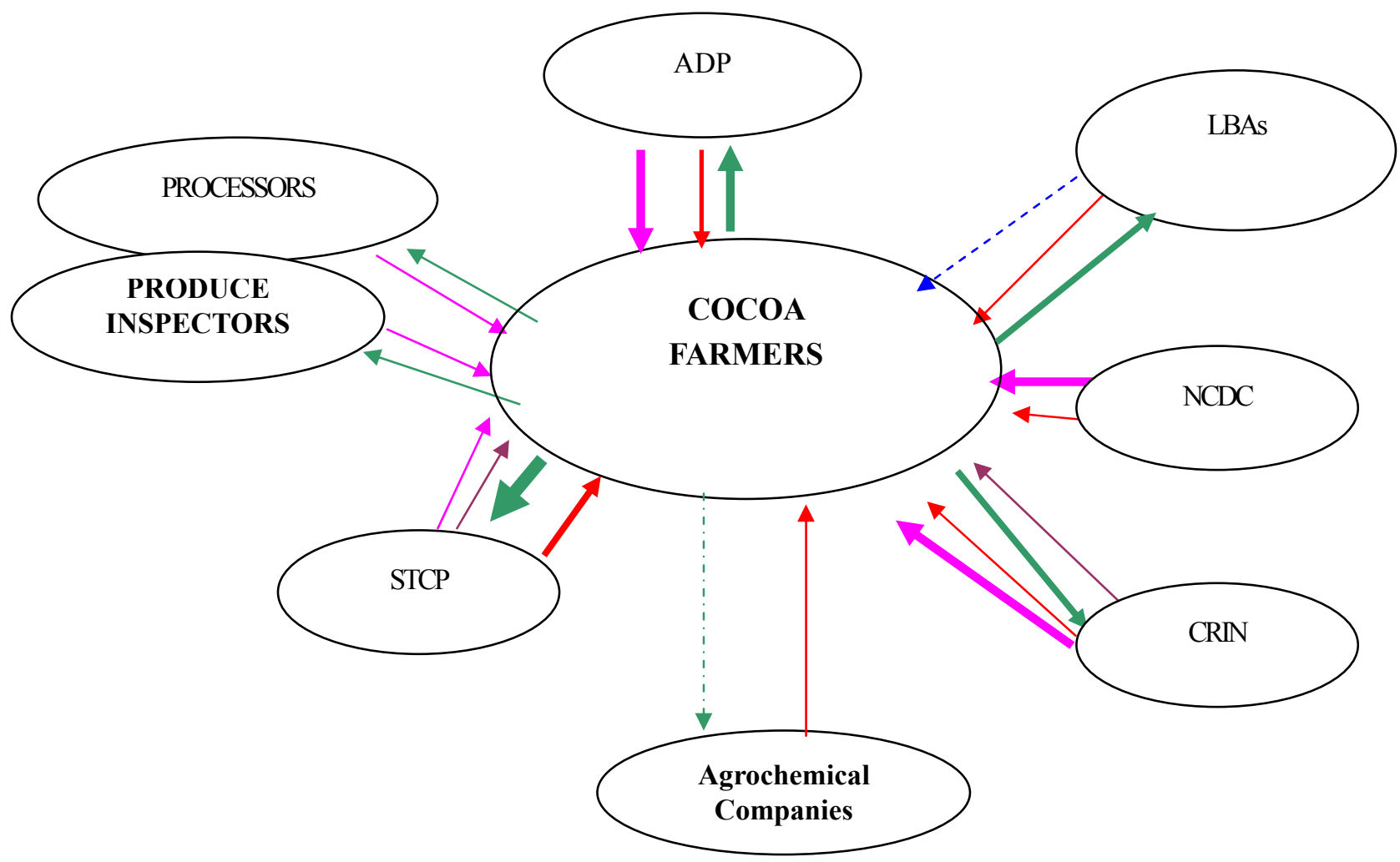

Key:

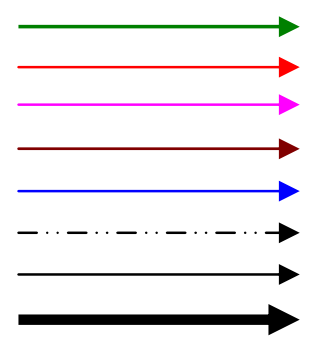

Feed Back

Information flow

Inputs

Technical Advice

Financial assistance

The thin broken line represents weak and non-regular support

Only thin line represents weak support

The thick line represents very strong support

Figure 1. Stakeholder analysis showing the interaction between stakeholders and farmers in Wasimi community of Ondo State 


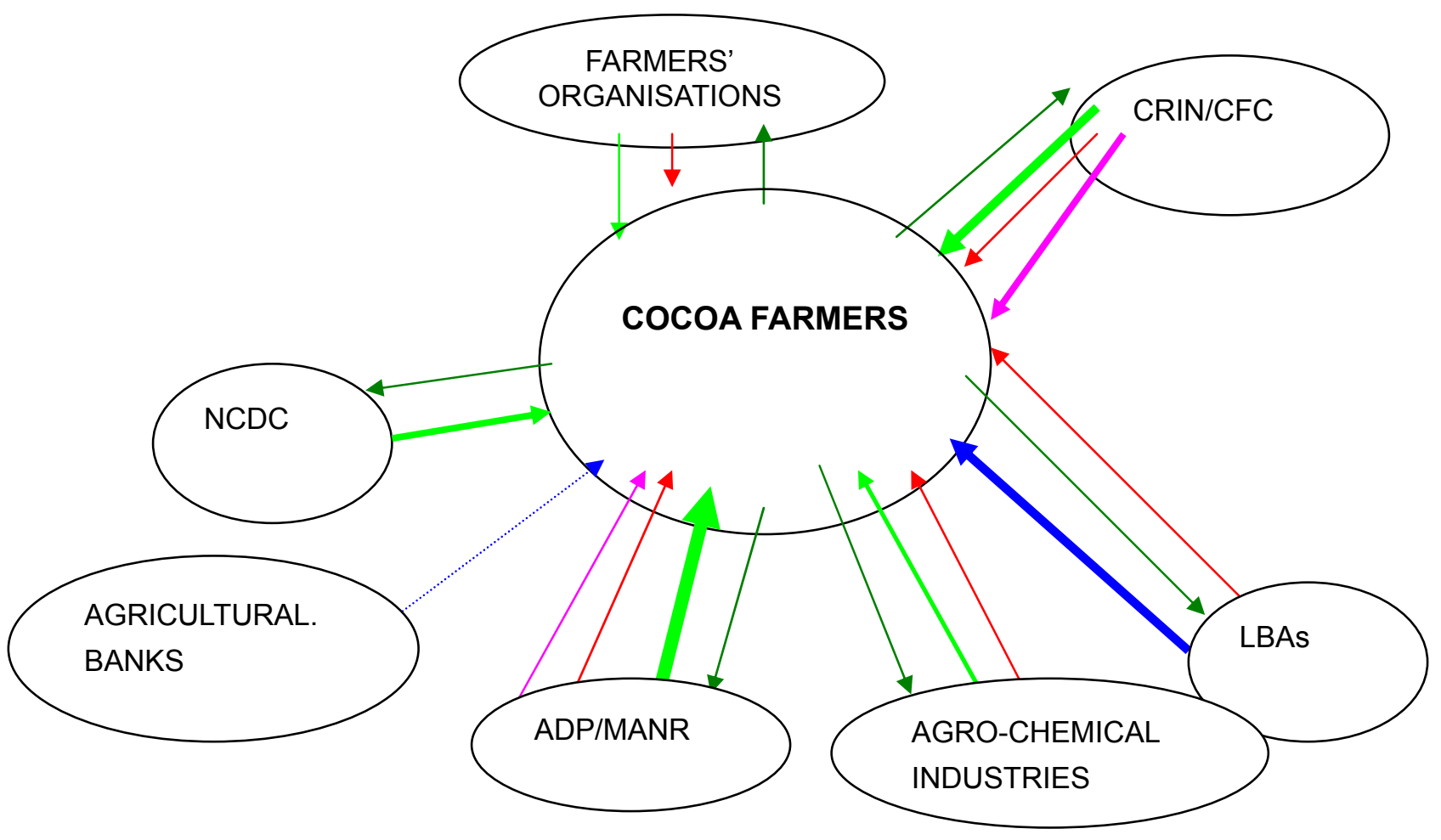

KEY:

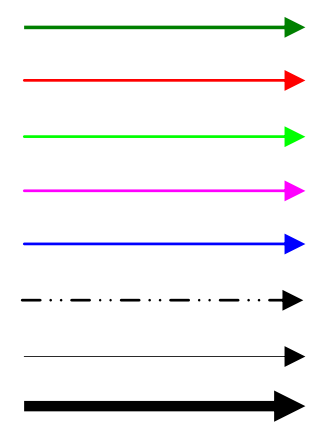

Feed Back

Information flow

Inputs

Technical Advice

Financial assistance

The thin broken line represents weak and non-regular support

Only thin line represents weak support

The thick line represents very strong support

Figure 2. Stakeholder analysis showing the interaction among all stakeholders and farmers in Ikoromaja community of Osun State 


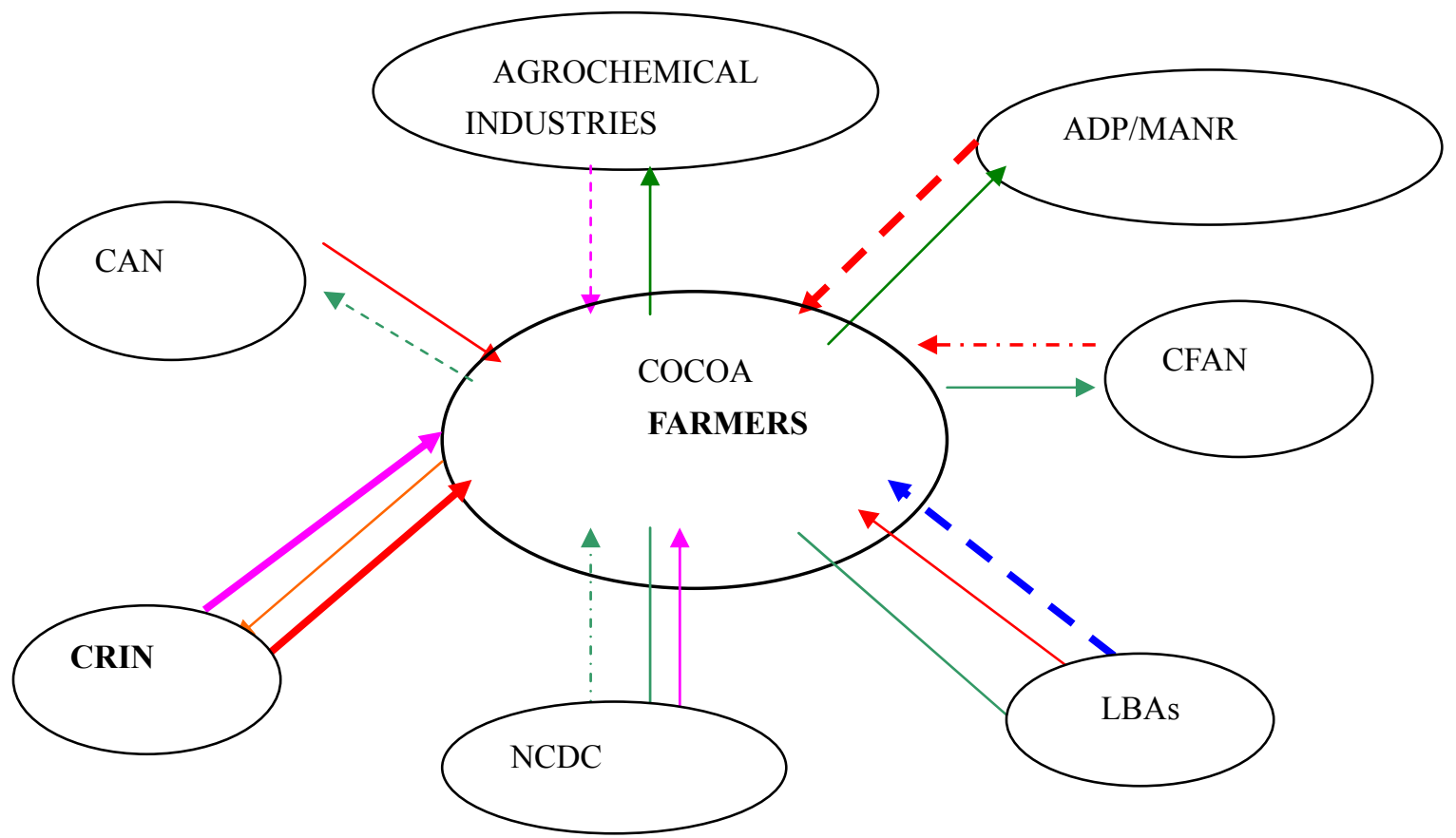

KEY: :

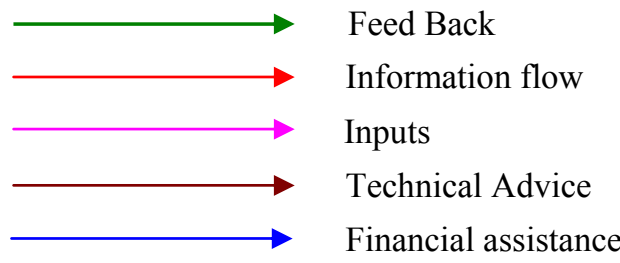

$-\cdots-\cdots-\cdots-\cdots-\cdots \rightarrow$ The thin broken line represents weak and non-regular support

$\longrightarrow$ Only thin line represents weak support

$\longrightarrow$ The thick line represents very strong support

Figure 3. Stakeholder analysis showing the interaction among all stakeholders farmers in Etomi community of Cross River State

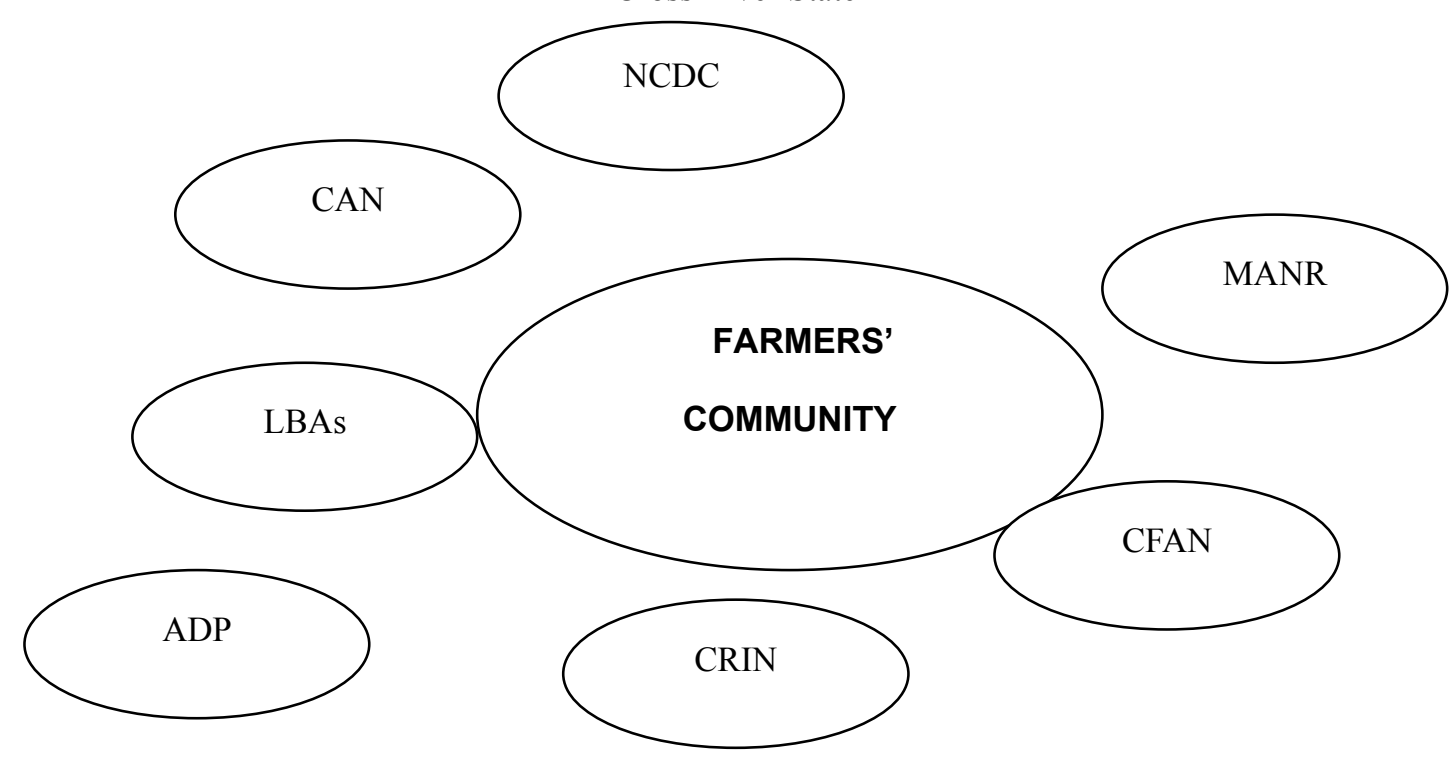

Figure 4. Venn diagram showing the closeness of stakeholders identified at Etomi village of Cross River State 


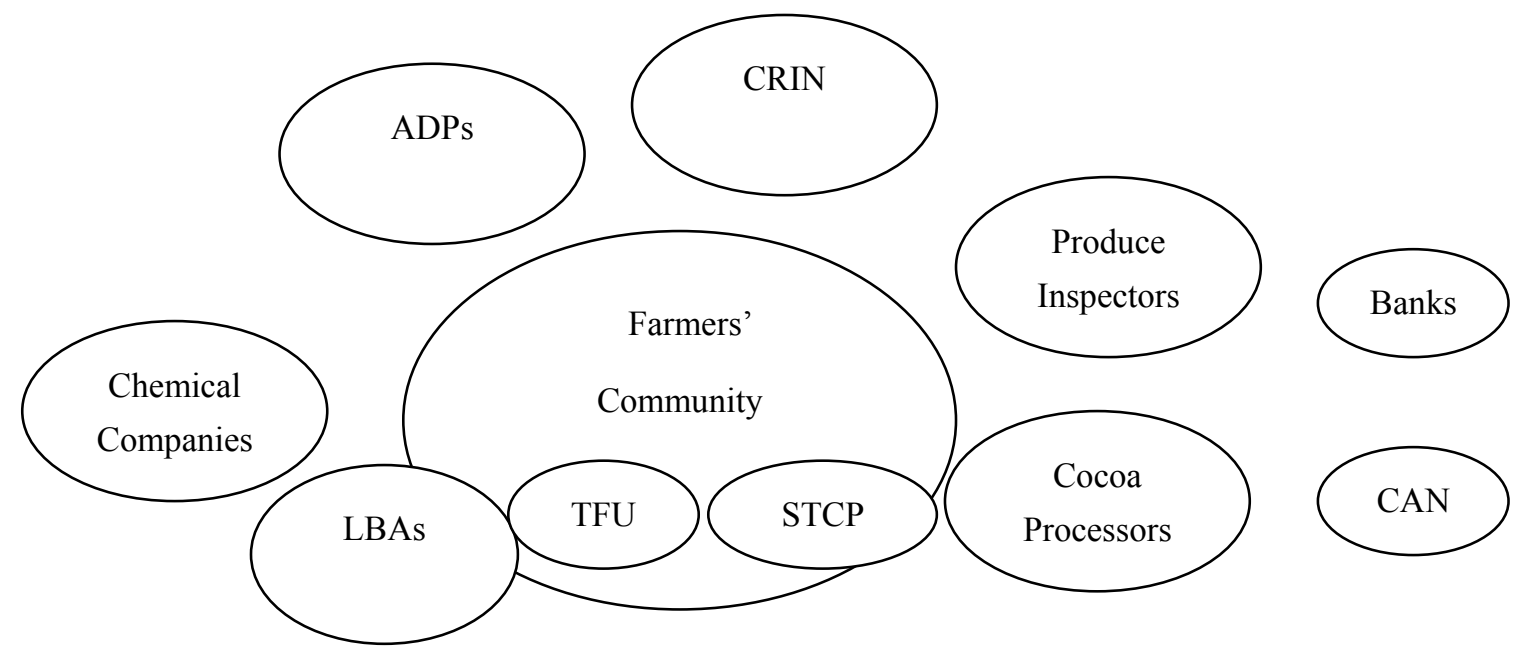
TFU - Tonikoko Farmers' Union
STCP - Sustainable Tree Crop Programme
CAN - Cocoa Association of Nigeria
LBAs - Licensed Buying Agents
CRIN - Cocoa Research Institute of Nigeria
ADPs - Agricultural Development Projects

Figure 5. Venn diagram showing the closeness of stakeholders identified at Wasimi Village in Ondo State

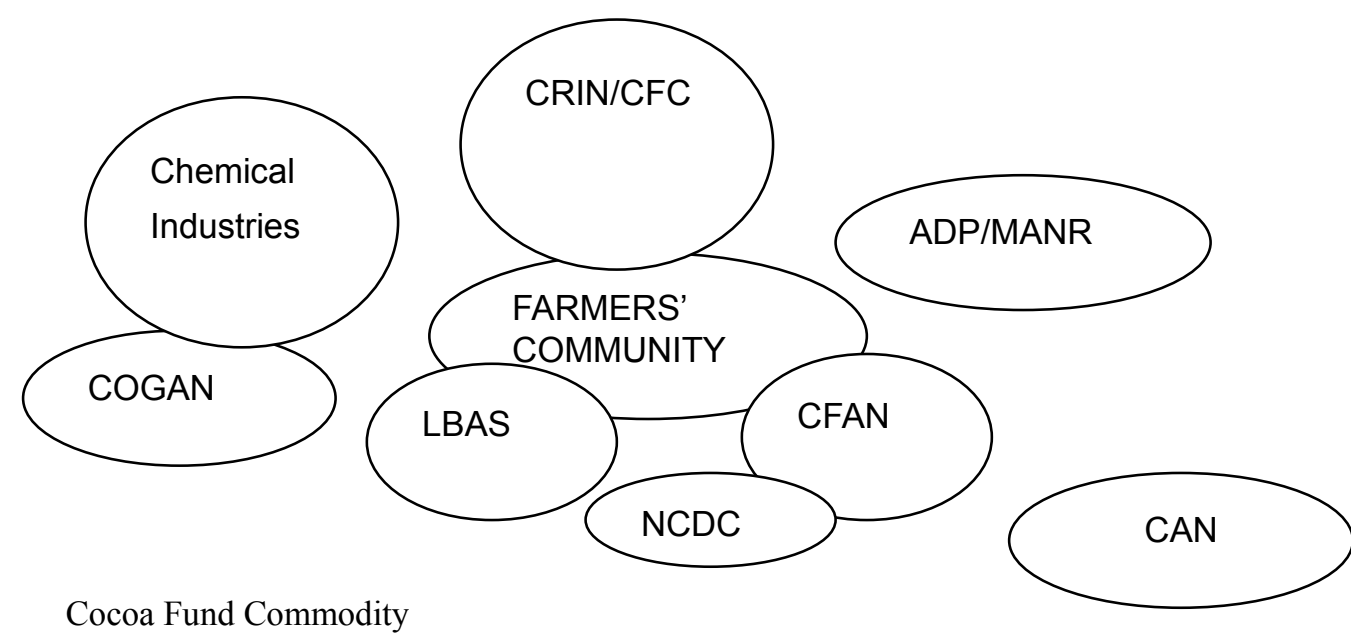

CFC - Cocoa Fund Commodity

NCDC - National Cocoa Development Committee

COGAN - Cocoa Growers Association of Nigeria

MANR - Ministry of Agric. and Natural Resources

CAN - Cocoa Association of Nigeria

CFAN - Cocoa Farmers Association of Nigeria

Figure 6. Venn diagram showing the closeness between farmers' community and stakeholders in Ikoromaja Village in Osun State of Nigeria 